\title{
PART THREE
}

\section{Village life}


Roxana Waterson - 9789004253858 


\section{CHAPTER XI}

\section{Women and men}

Relationships between women and men were the major focus of my initial field research, but it was a topic that I found to be especially elusive. The analysis of gender relations is forever unfinished business. In one sense, the subject is never closed because history is unfinished, and so the contexts in which we look at gender must be always changing. Feminist ethnography over the past twenty-five years has made a close and uncompromising engagement with the specificities of the particular social contexts in which women and men live their lives. Out of such fine-grained analyses, challenges have arisen to every attempt at a universal explanation of gender and its inequalities; the terms of the debate, and all of their hidden assumptions - about nature, culture, the public and the domestic, even notions of identity and the self - have been subjected to rigorous scrutiny, until now, even the idea that there could be such unitary categories as 'man' and 'woman' is seen to be naive. Current studies, instead, emphasize the multiplicity of roles, qualities and identities that persons may hold, not all of them gendered; the shifting and contextual character of gender constructs; the interplay of social positions, in which gender as a status marker may be over-ridden by other factors such as class, rank or ethnic divisions; and the variations in experience of femininities and masculinities (no longer to be thought of in the singular) that result. ${ }^{1}$ Distinguishing 'gender' from the persons of women, La Fontaine (1992:104) concludes: 'Gender does not adequately describe the complexity of women's roles and social actions, as we all know'. Or, as Howell (1996a:254) puts it, writing of the ambiguities of gender among the Lio of Flores: 'It is no longer valid to assume that there is one single model of gender in any one society and that the job of the anthropologist is to elicit it.'

1 See for example MacCormack and Strathern (1980); Strathern (1984, 1988); Davis, Leijenaar and Oldersma (1991); Ardener (1992); Moore (1994); Charles and Hughes-Freeland (1996), for expansions of these positions. A growing parallel literature sets out to complicate pictures of masculinity (Cornwall and Lindisfarne 1994; Connell 1995). 


\section{On multiplicity and ambiguity in gender analysis}

Studying gender in South-East Asia has presented its own special challenges to theory, precisely because it is not always given much social attention. Whereas some societies have obsessively elaborated gender differences as a basis for unequal social organization, and insist on the essential, intrinsic natures of 'male' and 'female', one finds many South-East Asian examples where gender categories appear symbolically underplayed and unmarked. The Toraja provide a notable example of such muting of gender differences. Yet, at the same time, there are undeniable, if subtle, asymmetries in the roles and statuses of men and women, often particularly noticeable in their differential exercise of political power, and their control of formal language such as oratory and ritual poetry. To borrow a phrase from Gregory Bateson, it appears that in these cultures, gender is not necessarily 'the difference that makes a difference'. ${ }^{2}$ Atkinson and Errington (1990) produced a pivotal collection of papers, significantly pointing in this direction, and attempting to move beyond a superficial assessment of women's 'high status' in the Southeast Asian region. Errington (1990:4) remarks in her introduction to these papers that up to that point few authors had gone further than to note the relative economic equality of men and women, and the paucity of symbolic expressions of gender difference. Was there not more to be said? The very subtlety of gender distinctions makes them all the harder to study, and their articulation with other dimensions of social organization has frequently been passed over; might this lack of social visibility be partly due to a difficulty of recognition on the part of the outside observer? And what if indigenous concepts of 'power' and 'status' themselves were to differ widely from those of the anthropologist? What seems clear is that in many South-East Asian societies, men and women are thought of as fundamentally similar, rather than intrinsically and irremediably different, types of persons, and the differences between them are not posited as based in their essential 'natures' as gendered beings. If there are roles that women rarely achieve in many Indonesian societies, it is not because these are prohibited to them; actors may attribute the differences to chance, or to an individual's possession or lack of spiritual qualities (without particular reference to gender), even if from the outsider's point of view there may appear to be structural factors that in practice hamper women from assuming these roles.

Moreover, shifting contexts play a crucial role in determining ways of acting and being. There would appear to be at least some social contexts in which gender is irrelevant or of no consequence. In eastern Indonesia, one does indeed find societies with considerable elaboration of male/female symbolism, but the

2 One can turn this around, of course, and posit that in gender relations, difference is produced by the suppression of similarities (compare Rubin 1975:180). 
stress is typically on the complementary pairing of these elements to create the harmonious fusion that ensures efficacy. In Bali, not only human beings, but a variety of other items including pigs, drums and slit-gongs need to be paired in order to function properly, though for ritual purposes the male/female counterparts need not necessarily be husband and wife (Hobart 1995:134). Howell (1996a) shows how among the northern Lio of Flores, in ritual contexts, 'male' or 'female' qualities may sometimes be represented by a person of the opposite sex, and 'need not be expressed in the bodies of actual men and women'. Such ceremonial contexts contrast here with those of daily life in which men do men's things and women do women's things. In Indonesia's bilateral kinship systems, and even in some which are not, as in Bali - see Errington (1990:2) - gender symbolism is largely notable by its absence, and here, too, the sexes may in certain contexts be substitutable for each other (Hobart 1995:139). Rank may over-ride gender as a status principle; being naturalised as it often is in discourse as a product of 'birth', it can be made to seem an even more immutable source of difference than gender, where gendered differences may be so contextually defined. Throughout the archipelago, gender roles tend to encompass a relatively flexible range of possible ways of being, with a widespread tolerance for cross-dressing 'third' genders, whose members have not infrequently played significant ritual roles as shamans or ritual specialists.

A good example of the concern with rank is provided by the Bugis. The Bugis are like the Toraja in having a bilateral kinship system, yet differ markedly in the relative separation of men and women in social life. A complex of honour and shame (siri') in the past required an unmarried woman to guard herself from chance contact with men outside the family, and her male relatives to defend family honour by attempting to kill both her and the man if such contact occurred. As Millar (1983:478) describes it (and certainly by comparison with the Toraja), in Bugis society 'the gender system is highly elaborated and formal yet not a master organizational principle', being here subsumed within a more dominant concern with hierarchy and social position (harga diri). Moreover she notes 'the complete absence of the notion that gender behaviour is dictated by biological propensities' (Millar 1983:488), the existence of a well tolerated third gender category of male transvestites (calabai), and the responsibilities women are expected to take in daily decision-making in the household. Men act as public spokespersons for the family, but they first of all listen to women, who have access to crucial information concerning everybody else's social statuses through their constant participation in gossip networks, and who 'usually have well-considered opinions on the social effects of various alternative choices' ${ }^{3}$ Women apparently do not view the fact that they serve

3 Millar 1983:489. A comparison might be drawn here with the roles of women and men in Minangkabau society, where the women, as powerful owners of inherited lands and houses, 
food to men as indicative of subservient status; both sexes tend to stress the opinion that men and women both have things they are particularly good at, that both are equally important, and their cooperation essential.

Various collections of studies (Van Bemmelen et al. 1992; Karim 1995a; Ong and Peletz 1995; Sears 1996) have continued to complicate the regional picture of gender relations by further documenting their fluidity, contextuality and indeterminacy. They probe difficult areas that pose a challenge to a too unproblematic assessment of women's status in South-East Asian societies, but they still present us with a dissolution of gender polarities that sharply contrasts with the kind of gender stereotypes that persist at the everyday level in Euro-American and some other cultures in the face of feminist deconstruction. ${ }^{4}$ Some of these writers also show how contradictory images of gender may coexist within a single society; or how folk models of equality may at times conflict with the actualities of power relations in the context of the modern state, whose ideological positions may in some respects offer women much less room for manoeuvre than indigenous social systems do (Karim 1995b:60; Sullivan 1994). In New Order Indonesia, women were primarily idealized as wives and mothers, and the wives of military personnel and civil servants were pressed into membership of parallel wives' organizations, effectively depoliticising them and pre-empting possibilities for women to organize themselves as they chose. As a foil to this, there lurked in the background the demonised and unmentionable image of Gerwani, the left-wing women's organization which was unfairly discredited and blacklisted in the aftermath of the 1965 counter-coup which brought Suharto to power (Tiwon 1996). Suryakusuma (1996) shows how intrusively the New Order attempted to regulate the marital lives of civil servants through bureaucratic controls, producing a quite distinctive sexual culture in this section of the population, marked by its patriarchal double standards, masculine self-indulgence and hypocrisy. Although the military and bureaucratic structures of the New Order extended throughout Indonesian society, from the centre down to the most local levels, I speculate that the gender ideology they produced may have had more oppressive effects on women in urban contexts, especially in Java, than in more marginal regions like Tana Toraja, where it was less likely to displace the already existing gender imageries of local societies. ${ }^{5}$

allow men the public leadership roles in representing clans and lineages, but where men are unlikely to act without the approval of mothers, sisters or wives (Tanner 1982).

4 See for example Hughes-Freeland's (1995) penetrating analysis of female and male dance styles in Yogyakarta as expressions of energy and inner spirit, which defies stereotypical notions of masculine superiority assumed by some other writers on Java.

5 The debate about gender in Java is as vexed as anywhere in the archipelago, perhaps more so, since the undoubted subtelty of indigenous gender philosophies is complicated by the potential contradictions between Indic and Islamic modes of thought (Freeland 1995:199), as well as 
By contrast, some of the most recent writing on women in Indonesia (Robinson and Bessell 2002; Satriyo 2003) has been concerned to explore how far the new politics of devolution, at that point under Megawati as a female (though not noticeably feminist) President, might offer new opportunities or hindrances to women. Ordinary people's new awareness of their right to participate in the political process is a potentially very positive factor, and in some areas (less so in Tana Toraja) there has been an explosive growth in the number of NGOs, including women's organizations. But women are still chronically under-represented in Indonesian politics generally. In some regencies the impetus to reinstate adat structures or enforce conservative religious rulings without first entertaining any popular debate has been disadvantageous to women (Satriyo 2003:222). So far as adat is concerned, this should not pose any threat in Tana Toraja, where I could discover no point of adat law which discriminates against women. But women remain as underrepresented in local politics in Tana Toraja as elsewhere - a fact which, given the degree of equality that typifies other aspects of gender relationships, presents itself as a puzzle.

\section{Gender as an unmarked category in Tana Toraja}

The studies discussed above all help to provide a context within which to situate a discussion of the underplayed, and at times ambiguous, character of gender relations among the Toraja. We have already seen that the bilateral tracing of descent grants children of both sexes equal inheritance rights. No strong preference is expressed for girl or boy children, but both are valued. Adat law does not discriminate between the genders, save that, after a divorce, a woman is more likely to win custody of her children. ${ }^{6}$ Residence after marriage is most often uxorilocal, which means that a woman is often the house owner, since the house is built on her family land. If there is a divorce, the husband must leave, though he may receive the rice barn as compensation. Minimal ceremony attends a marriage, and divorce is unproblematic, though either party may be subject to a fine to be paid in buffaloes (the kapa'), fixed at the time of the wedding, if they are held responsible for the failure of the

\footnotetext{
by marked differences of class (the writings of national heroine Kartini providing a well-known illustration of the traditionally restricted lifestyle of upper class women; see Tiwon 1996), and the contrasting lifestyles of rural and urban populations. Added to this is the greater accessibility and therefore influence of the mass media here than in more marginal regions of Indonesia; here as elsewhere in the world, TV and women's magazines portray images of femininity that may be more disabling than those of indigenous local cultures.

6 This tendency is modified by the fact that, from a rather young age, the children themselves would be free to exercise their own choices about where they want to live.
} 


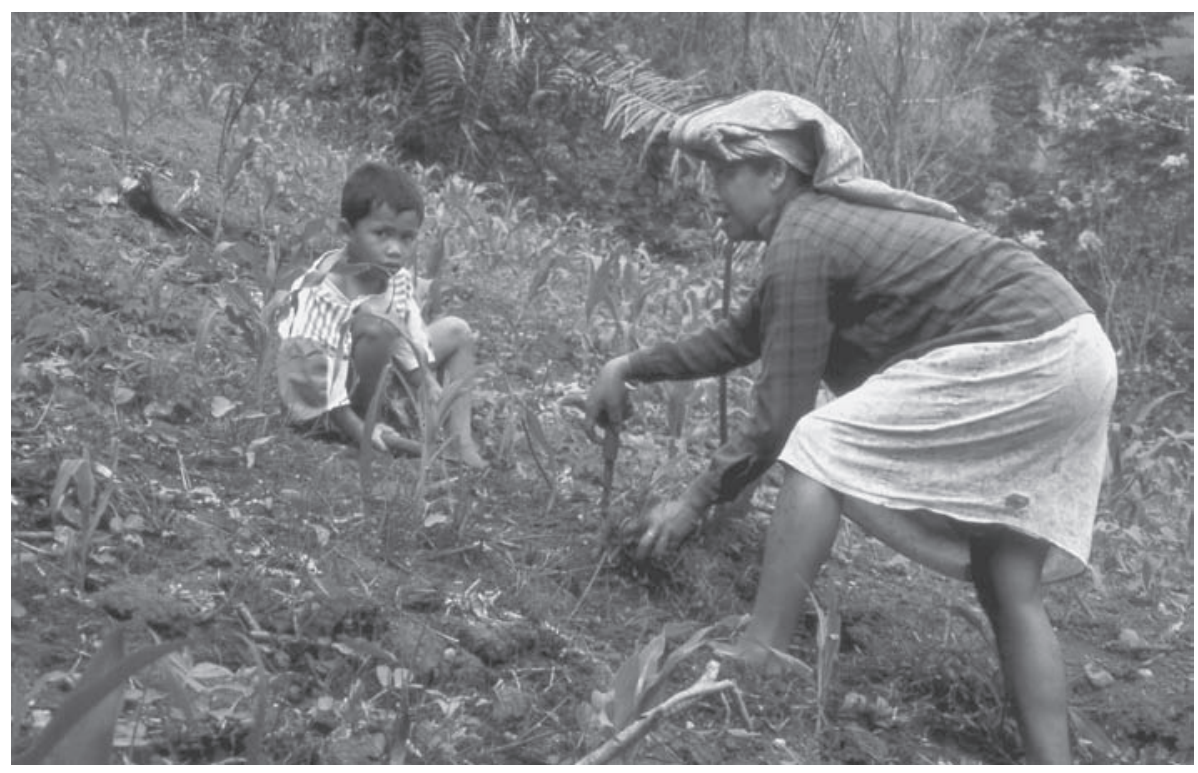

Sebo', accompanied by her youngest son Peppry, working one of her hillside gardens, 2002

marriage, for example by adultery. If a couple cannot get on together, people may simply accept that they are not not meant for each other (tangsidalleran, 'they do not share the same destiny').

On balance women do more work than men, since they play an active part in rice cultivation, especially the planting and harvesting, as well as cultivating vegetable gardens, rearing pigs, child care, preparing food, and fetching water. Men do ploughing and heavier work on the land, and must provide their wives with firewood. There is a complementarity in the provision of wood and water for the household; nale'tokan kayu, 'he splits wood for her', or naalan kayu ('he fetches wood for her') are expressions meaning that a couple is regarded as married, even if they have not had any marriage ceremony (as opposed to merely having an affair), because the man is seen to be contributing to the household. After the harvest, the woman takes charge of the rice barn and manages the household's food resources; only she enters the barn and a husband who interferes in her responsibilities will be mocked as muane daru', a term which has strongly negative connotations of being bossy and stingy. ${ }^{7}$

7 This female management of food resources and their distribution is characteristic of a number of other Malay and Indonesian societies (Karim 1995b:50 note 7). Toraja particularly condemn a man who, through meanness, tries to prevent his wife from sharing things or show- 


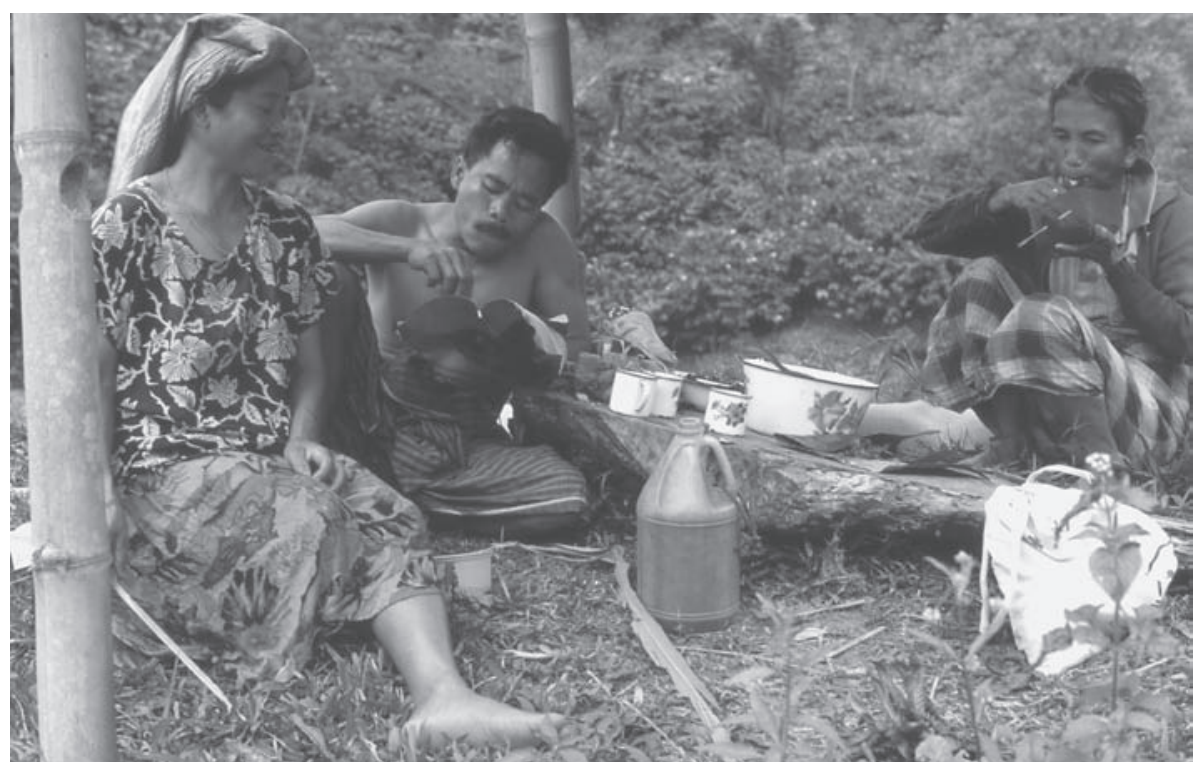

During the busy ploughing and planting season, Indo' and Ambe' Bolle' and their neighbour take a break to eat lunch beside the rice field, 2002

Women's capacity as mothers is honoured in the ruling which says that a wife should have slightly more buffaloes sacrificed at her funeral that her husband. Dadi ki' lan lino, baine umpodadiki' ('when we come into the world, it is women who give birth to us'), one man explained to me in explanation of this ruling. Napasolo' $k i^{\prime}$ indo'ta, 'our mother carried us in the womb', is another phrase used to express this debt owed to the mother. The father, it is said, 'only looks for food', but the mother carries us, gives birth to us, and nourishes us. With regard to women's rights of inheritance, a slightly more ambiguous statement was made by one acquaintance, who said: 'If there are only two children, and three rice fields, the sister should get two and the brother one, because we feel compassion/affection for her, since she can't search for her own livelihood in the same way as a man.' 8

ing hospitality to others, or who intervenes in decisions about household budgeting. It does not mean doing women's work as such, though, such as cooking or sewing, which men sometimes do to help out. Technically, I was told that a woman could be termed baine daru' if she tried to interfere in men's tasks, such as ploughing, but this seems unlikely. Both conditions may be said to be rare, though I did encounter one case of a woman who sought a divorce from such a man. He ended up living with his sister, and seemed to stand little chance of remarriage, since women laughed at him and said: Minda la umpomuane tu? ('Who would take him as a husband?').

8 Sanday (1990:148-9) reports of Minangkabau men that they sometimes justify the matrilin- 
In some societies, rituals of the life cycle, particularly initiation and marriage, provide dramatic opportunities for acting out and inscribing on the bodies of the participants the differences between male and female. Such rites are virtually non-existent in Toraja. The only exception is mortuary ritual, which is enormously elaborated, but along lines of social rank, not gender. Otherwise, life crisis ceremonies are few. A small rite (called $m a^{\prime} k u^{\prime} k u^{\prime}$ ) used to be held for a child when its hair and nails were first cut, usually at about a year old. Noble families would mark this occasion by killing a pig, and commoners a chicken, and the child would be named at this time. Only a token piece of hair may be removed, but after this, small children of both sexes may have their hair shaved. Traditionally, a small tuft called the patondon, left at the front of the head, indicated that the child was of noble birth. There are no public initiation rites, though boys approaching puberty may make a personal decision that they are ready for supercision of the penis (ma'tille) (in which a longitudinal cut is made on the top of the foreskin), which is done privately by an experienced older person, usually at the river bank where the cold water helps to reduce pain. ${ }^{9}$ After this a boy will not go around naked any more, as small boys often do. ${ }^{10}$ Nor does any rite accompany the onset of menstruation, which is a strikingly unmarked category in Toraja. Until recently, marriage rites never involved more than the sacrifice of a single pig. The groom would come in the evening with a small party to the bride's house, where both of them would sit and listen to good advice dispensed by the elders of the community. This has changed under the influence of Christianity, and Christian weddings now can be quite expensive, as will be further discussed in Chapter XII.

A most striking aspect of the underplaying of gender differences is the lack of any concept of female pollution, so characteristic of Indian, Chinese, and Judaeo-Christian civilizational complexes, not to mention Melanesia. It simply is an unmarked category in Toraja. Women expressed no great concern for secrecy about menstruation and said they were unconcerned if blood might show on their clothes. I could not learn of any rule against intercourse

eal system as being designed to protect women because they are weaker, and yet, as in nature, the female is the one who gives birth. 'Just as the weak becomes the strong in nature, we must make the weaker the stronger in human life'.

9 Hollan and Wellenkamp (1996) mention tooth filing ( $m a^{\prime}$ kiri') for both sexes, and also scarification of the forearm with burning embers ( $m a^{\prime} b a r u k$ ), practised by boys, apparently under the influence of peer pressure rather than any formal organization by adults. These practices have died out, and neither of them were ever mentioned to me by people in the area where I lived.

10 Some men used to have a wood or bone penis pin (called takki' or talede) with knobs on the ends inserted in a hole pierced at an angle starting behind the glans and going down through the penis. It was claimed to give great pleasure to women. By the 1970s I was told only a few very elderly men still had one. Penis inserts were formerly quite widespread in Southeast Asia (Brown et al. 1988). 
during a woman's period, or any idea of menstruation as posing a threat to men's spiritual or mental health. ${ }^{11}$ Neither is there any restriction placed on women after childbirth, or any rite of reincorporation into society after the event, such as is typical in societies where childbirth is marked as a polluting event. The father's involvement at the birth, already noted in Chapter $X$, is indicative of this absence of ideas about pollution; his responsibility of burying the placenta is a task that would be considered seriously endangering to a man in most New Guinea societies, or other cultures where images of defilement surround women's reproductive abilities.

These abilities, then, are not devalued, as in the world religions, where they are deemed to render women inherently less 'spiritual' than men. Neither do men arrogate to themselves, as in some Melanesian societies, the cultural power to ensure fertility in secret rituals in which women cooperate only by agreeing to be excluded. Women take part in all Toraja rituals; in fact their participation is a necessity. The aim of a large part of the Toraja ritual cycle (the so-called 'Rites of the East' or of the 'Smoke of the Rising [Sun]') is the enhancement of fertility and prosperity. Women play particularly significant roles in rites of this kind, including in the past a kind of priestess called the to burake tattiku', who functioned in the great $m a^{\prime} b u a^{\prime}$ ritual (Waterson 1984; Nooy-Palm 1986). This role has almost died out because the ceremony is now rarely performed; the same is true of the formerly high-ranking transvestite priest called to burake tambolang, whose person in uniting male and female elements was particularly well fitted for communication with the deities (deata). ${ }^{12}$ As elsewhere in South-East Asia, the symbolic emphasis in ritual is on the maintenance or restoration of cosmic harmony, and where this is gendered, it demands the bringing together in balance of male and female elements, a creative fusion that guarantees well-being. Several other ritual roles must be performed by a husband and wife pair, as I shall discuss below.

\footnotetext{
11 Hollan and Wellenkamp (1996:117) report from the northerly region of Toraja where they did fieldwork: 'While the Toraja have few clear notions of menstrual pollution [...] there is a widespread belief that sexual intercourse during menstruation may cause the man or the woman or both to become ill.' I did not encounter any such idea, however, so I assume there is some regional variation here. For another South-East Asian society where menstruation is 'unmarked', see Appell (1988) on the Rungus of Borneo. The absence of the topic from the index of various ethnographies on Indonesian societies, or its discussion only in terms of the positive values associated with fertility, is indicative of the relative lack of emphasis which I believe is typical in this area. Notable exceptions are Bali, where Indian influence means that women may not enter Hindu temples while menstruating, and Maluku, where distinctly Melanesian cultural influences can be detected.

12 Elizabeth Coville, however (personal communication) did encounter surviving to burake in the remote northwesterly district of Tana Toraja where she did fieldwork in the early 1980s. See also Nooy-Palm (1979:282-9). I discuss the $m a^{\prime} b u a^{\prime}$ as I witnessed it in Chapter XV. Buijs (2003) describes the even more striking and prominent roles formerly played by women in the rituals of the Mamasa Toraja.
} 
We have already seen how the lack of symbolic differentiation between genders is carried through in Toraja ideas about the indivisibility of kinship substance, and the undifferentiated contributions which the two sexes are believed to make to the conception of a child. In tracing descent, this lack of differentiation between genders can also be seen very clearly. Genealogising is an activity which tends to take different forms in different kinship systems. In a patrilineal system, female ancestors may disappear from memory because only male names are remembered and recounted. Toraja presents a different kind of difficulty for the anthropologist. When people recount or write down their genealogies, these always start with a founding couple who established a particular origin house (tongkonan). But, lower down the generations, they often do not recall the sex of some individuals (something it is frequently impossible to tell from the name itself), or, if written, the names are unaccompanied by any distinguishing symbols. Instead of one gender being remembered at the expense of the other, gender is simply forgotten, which can only mean that it is not seen as relevant or important. And indeed, this accords with the equal emphasis placed on tracing links through male and female kin, and the equal rights of inheritance enjoyed by both men and women.

\section{Pairing and balance in marital relationships}

Marriage as an economic partnership requires the spouses to exert themselves to attend ceremonies, or help in house construction, more or less equally on both sides of the family. They also share responsibility for meeting ceremonial debts which they may both have inherited from their parents. In practice, since men are often living with their wives, they may quite frequently be helping in the renewal of one of her origin houses. This makes sense particularly if they are resident in it. And a husband, women told me, will be the first source of support if the wife must arrange to make funeral sacrifices at the death of her parents. This can be of crucial importance in southern and central districts of Toraja, where a competitive system of sacrificing is followed, such that the share of inheritance finally claimed by each child of the deceased is calculated according to the relative size of their funeral contributions. A woman in this system must stand up for herself against siblings who may be aggressively competitive, but she can count on her husband's support. This is logical for him too if there is land at stake. In the absence of a husband, other relatives may also help her if necessary.

A major goal of marital cooperation is to meet ceremonial obligations. Funerals (discussed at length in Chapters XVII and XVIII), are among the most frequent and important of these occasions. Every adult is to greater or lesser degrees bound up in relationships of credit and debt incurred by the 
giving of pigs and buffaloes as funeral sacrifices. The responsibility to make such gifts to affines is especially strong. Men in particular use the funeral ground as an arena to build local reputations for 'boldness' in presenting buffaloes and pigs for slaughter, though women also may give livestock on their own account. ${ }^{13}$ Generally, however, husband and wife work as a team to meet their ritual responsibilities to relatives on both sides. The role of women in feeding pigs is very essential here; one woman friend in her sixties confided to me that she had never in her entire married life been able to sell a single pig (to meet other needs such as paying for children's education), because as soon as one was large enough to sell, it was always needed for some ceremony or other. One is prompted here to consider a comparison with other prestige economies which rest heavily upon pig-rearing, as for instance in New Guinea. Much has been written about those economies as ones in which women play essential roles as producers, yet men hog the limelight as distributors of the wealth they create. Is this the case in Toraja also? It seems less clearly so, partly because of the balance of attentions paid to wife's and husband's relatives. If the husband's name is more likely to appear on the official lists now recorded at the entrance to the funeral ground, where slaughter tax must be paid, still, it will be well known to those present whether it is his affines or his wife's who are the recipients. And it is arguably to houses and their kinship groupings (particularly those of high rank) that honours ultimately accrue in this system, rather than to men as a class.

In daily life, too, mutual cooperation tends to be stressed. A spouse may be affectionately referred to as sangayoka or bali tedong, both expressions in which one characterises oneself as one of a pair of buffaloes pulling a plough together. Unless they exert themselves equally, the ploughing will not go smoothly. Spouses should support each other or 'pick each other up' when difficulties arise (pada siakkaran). When I asked women what qualities made for a good marriage, a typical response was: 'A good man helps his wife and doesn't gamble too much. And a good wife helps her husband.' Most commonly mentioned as a desirable trait was that a man should not be bad-tempered (to sengke-sengkean). In fact, domestic violence would seem to be rare, not least because if a man is living in his wife's village, her parents or other relatives will soon intervene to prevent it, and will probably press her to divorce him. This impression is borne out by Hollan and Wellenkamp (1996:110):

Indo'na Sapan also claims that women will divorce husbands who physically abuse them: 'If a husband likes to hit [his wife], the wife will become sick at heart.

13 Hollan and Wellenkamp (1996:166), for instance, mention a divorced woman who was proud of her success in upholding ties with important families through her own ceremonial giving of livestock. 
[She will think,] 'I don't want this. I want to be free [...].' People must get divorced [after such incidents] [...]. Women will run from a man like that. Who would want to be hit like that? Even our parents don't hit us like that! Besides, husbands [who don't hit] are easy to find.

They add that men are also likely to be intolerant of bad temper in their wives. Furthermore, they found that Toraja generally place a high cultural value on emotional equanimity, and believe that emotional discord can lead to ill health and misfortune (Hollan 1988; Hollan and Wellenkamp 1994:72).

The low level of violence in relations between men and women deserves some further comment. In many other societies, including Europe and the Americas, domestic violence is commonplace, even if disapproved of, and in urban industrial societies we all have to live with the awareness that a few men are pathologically violent toward women. Feminists have commented searchingly on the continuum of soft to violent pornography in Western societies, and the repetitive representation of women as victims in movie thrillers, considered as entertainment. Even if we don't experience violence directly in our personal lives, we do have to incorporate these images into our total picture of how the genders relate. Reviewing the Euro-American sociological literature on masculinity and male dominance (which generally lacks a crosscultural emphasis even where it is sensitive to history), it seems that authors cannot escape from the apparent inevitability of men's oppression of women. Strathern (1988) has shown that notions of men and women as active/dominant versus passive/submissive are so deeply embedded in Euro-American societies that we risk being trapped by our own language, which makes it difficult even to express alternative perspectives clearly. Works exploring the possible evolutionary or psychoanalytical bases for such a setup (with titles like Demonic males (Wrangham and Peterson 1996) and Why men hate women (Jukes 1993)) may provide temptingly universalizing theses to explain it though they seem singularly unhelpful in making sense of the Toraja picture. Ethnography from other parts of the world also provides examples of cultures in which men's violence toward women is taken for granted, in a way that draws a stark contrast with the tone of Toraja relationships. P. Harvey (1994) for instance describes high levels of marital violence in the Peruvian Andes as something that women tend to accept as inevitable, and it is very difficult for them to challenge the legitimacy of a husband's right to beat them. Instead, as good Catholics, they are encouraged to draw religious solace from identifying their own sorrows with those of the Virgin Mary. One woman described her marriage as very happy, even though she and her husband fought constantly, apparently because he beat her marginally less severely than her father had (P. Harvey 1994:77). Where parents make a habit of beating their children, violence is already a part of the pattern of kin relations even before marriage. 'Children', writes P. Harvey (1994:70), 'are [...] brought up in an 
atmosphere of imposed hierarchy where respect is demonstrated by their parents' ability to beat them'. By contrast, Toraja parents rarely hit their children; hence the significance of Indo'na Sapan's remarks, quoted above, to the effect that a spouse can hardly get away with abuse where even parents do not exercise a violent authority. ${ }^{14}$ Since women are property owners and can count on family support, there is nothing to prevent them maintaining their own livelihoods in case of a divorce, and most divorced people will remarry sooner or later.

In the indigenous religion of Alukta, noble houses in a community were the ones which held certain ritual offices, particularly relating to stages of the agricultural cycle and to some of the fertility-oriented 'Rites of the East'. The title belongs to the house, and whoever is resident in it would carry out the duties associated with it. An important title was that of Indo' Padang ('Leader [literally, 'Mother'] of the Land'), who led the performance of agricultural rituals and always made the first offerings of the season in a particular, sacred rice field. Most often a man would be named to me as holder of this title of 'Mother', but some women stated emphatically that it was really the woman and her husband who were the holders, since as with other such titles, while the man takes charge of the slaughter of livestock for offerings, and the division of meat, the woman always cooks rice (the other essential element of the offerings) and ceremonially serves it with a wooden spoon for the offerings ( $m a^{\prime}$ sanduk). In my Buttang family it was the wife, Indo' Teken, who was the resident descendant of the house, her husband having come from a neighbouring village. She was therefore the official holder of the title of Indo' Kalo' ('Leader of Irrigation Channels'), but she needed her husband to kill the pig that had to be offered beside a stream at the time when the rice was beginning to ripen (ma'bulung pare). A distinctive feature of the Indo' Padang's responsibilities is that he was not supposed to travel far from home while the rice was ripening, and if he did, he had to take some uncooked rice from his own field with him, instead of eating other peoples'. The woman of the house holding the title in neighbouring Pasang village, however, explained to me that this duty fell more upon her than on her husband; she stressed that this task was best executed by the woman, who is the one who in her close association with the house exemplifies the quality of staying put (mari'pi), which here has a ritual significance. Amid the emphasis on balance and pairing, her comments hint at an element of difference between men and women, a difference which I shall now examine more closely.

14 Compare Benjamin (1994) on non-violence in Temiar relationships. Temiar parents feel so spiritually engaged in a dialectical relationship with their children that even to smack them is believed to pose a serious danger to the spiritual health of the child. 
Mobility and stability: elements of difference in the characterisation of gender

When people talk about the characters of men and women, they sometimes classify men into three 'types', according to the degree of their interest in gambling. Gambling is sometimes described as an aristocratic pastime; we have already examined its disruptive effects on Toraja society at the close of the nineteenth century. However, the place of cockfighting (always accompanied by gambling) in some important ritual contexts strongly indicates that gambling has a longer history in Toraja than present-day detractors are prepared to admit. Today it is associated with masculinity in a very general sense, though isolated instances of women gamblers may be mentioned. Strenuous efforts were made to enforce the government prohibition against all gambling during the 1980s and 1990s, but there has been a marked relaxation of this position since 1998, leading to an immediate resurgence of cockfighting and to jokes that for Toraja, in the absence of much other noticeable reform, Reformasi (the mood of political and democratic reform which was much talked of in the first years of the post-Suharto era) has meant chiefly a reformasi saung ('a reformation of cockfighting').

Of the three types of men, the first is the pattangga', who, although he may be a farmer in name, makes gambling his profession. Second is the passolle', who, while he may take gambling rather less seriously, prefers idleness to industry. The passolle' is a dandy whose other characteristics typically include a love of drinking, wandering and womanising. He may claim magic powers, as a sign of which he grows his hair long or wears a small scarf or towel knotted round his head like a bandana. Thirdly, the large majority of men may be said to fall into the category of the to bassa' (literally, 'busy') - the farmer who works hard and for whom gambling is only an occasional pleasure. There is no comparable classification of women into types depending on their attitudes to work and leisure. Indeed, women have less free time in any case. Still, at different times in their lives they may be more or less tied by household responsibilities; I once heard young women in conversation draw a contrast between married women who were like the serre' datu, a 'house cat' which always stays inside and never touches the ground, and their own relative freedom of movement while unmarried, as tedong lamba', or 'feral buffaloes', which are left to wander the hillsides. Women cannot really roam as much as men do, but certainly in the past, premarital relationships were rather uninhibited, girls and boys often going about in groups to meet each other.

In a way, the three 'types' of men may be viewed in terms of their commitment to their wives. Women, with their interests in land and houses, appear as the more stable elements of society. They have much to lose from a gambling man, since a major cause of land changing hands is in pawn as a result of gambling debts. Some men are not above pawning the land of a wife 
or female relative on the sly. A man who gambles is always wandering about instead of staying at home to work the land, visiting other people's homes and staying up all night to play cards or dice. Thus he has many opportunities for making the acquaintance of different women, which is the reason gambling and womanising are often said to go together.

The characterisation of men as mobile and women as fixed is one that is widespread in Indonesian societies, but its resonances are not necessarily the same as those we may bring with us from other cultures. Association with the house, that focal institution of most Indonesian kinship systems which is regarded as the source of life and nurturance, is not the same thing as a confinement to 'domesticity', and is hardly to be denigrated. Women's movements are not restricted in daily life, save that they should be seen to travel around only with good reason and not aimlessly, which men can get away with. Women travel frequently and without interference to work in distant hillside gardens, to trade in the markets, to visit relatives or attend rituals, for example. Immobility, as we have seen, may be associated with ritual power - in fact examples abound in other Indonesian societies of the association of this feature with power, both ritual and political (Waterson 1990:191-6). The most remarkable ritual instance of women's 'staying put' is the seclusion of a group of young women for an entire year leading up to the culminating performance of the $m a^{\prime} b u a^{\prime}$ pare, the greatest of the Rites of the East, associated with rice and fertility, also known as ma'bua' baine or 'women's ma'bua'. This rite is described in detail in Chapter XV.

One other reason for wandering may be the development of a calling as a healer (to ma'dampi), usually after a period of 'craziness' in which the individual wanders off alone up mountains, having visions and receiving powers from the deities of nature (deata). Both women and men may have such experiences. One woman in Buttang, whose grandfather had been a well-known healer, had herself also been a healer; but she told me she had given it up, although she still worked as a midwife. 'I'm a woman, and couldn't cope with it' (Baine ki', na tangdiupu') was her explanation, but my initial assumption that she referred to some intrinsic weakness of women was mistaken. She meant that it was just too awkward to have to travel around to visit the sick when people called for her services, when she also had a house to run, children to look after and pigs to feed. Other women healers I met operated very locally, but some who were men might indeed travel far and wide, until they got too old to. This is a good example of the sort of pattern which Errington (1990:57-8) sees as typical of island South East Asia, where assumptions about differences between people (in this case, men and women) tend to rest less on anatomy and more on the kinds of activities which people engage in.

Given the secure and strong position that women occupy in economic, kinship and ritual terms in this society, it remains a problem to explain 
why they should play so little part in politics and rarely speak authoritatively in public. Once again, Toraja commentary on this issue reveals some ambiguities. When pressed to explain this fact, people often formulate their comments in a way that amounts to saying: 'women and men are equal, but actually men are dominant', or conversely, 'men are superior, but actually men and women are equals'. Maleness is explicitly associated with eloquence or authoritativeness of speech in the phrase ma'kada muane (literally, 'to speak like a man'), but that is a quality that both men or women may possess; it can mean simply to be decisive or stand up for oneself. The ability to speak with style is also described as an attribute of high-ranking individuals. At the time of my first fieldwork, I several times had the opportunity to meet an elderly aristocrat, Bine' of Tombang in Menduruk, who was well known for her authoritative manner of speaking and was often called to participate in local village councils (kombongan) called to settle disputes. She was a great source of information about local history and older customs. She was something of an exception; there is no denying that such public roles are more commonly taken by men. On the other hand, since she had the capability and the inclination, as well as the inherited rank, to perform this role effectively, nobody thought it unsuitable for her to do so. Again, there are several examples of women who acted as village or district leaders in the pre-colonial or colonial times, because of their high status and, often, the absence of appropriate male family members. In the district of Nanggala in more recent decades, it was a female member of the ruling aristocratic family who was for long the dominant figure, being known to all by the respectful title of silndo' ('Mother').

The general absence of women in government positions such as village or district heads is, however, still very marked today. In 1983, I met one of three women who had recently been appointed as Kepala Desa, and since the 1990s have heard of a few others. All, to my knowledge, come from aristocratic families. Whether the absence of women in local government reflects their own reluctance, or simply the attitude of central government, is open to question. Some informants commented that they had heard women much more commonly held such positions in Java, but Sullivan (1994) paints a similar picture of the political sidelining of women in her study of a Yogyakarta neighbourhood. Sullivan concluded that the dominant nationalist ideologies of the New Order offered relatively little scope for women, whose potential contributions to development were liable to remain underutilized. ${ }^{15}$ As already

15 Compare the comments of Saraswati Sunindyo (1993) on women in New Order ideology. Such contradictions concerning the relative prominence of men and women surface even in the strongly matrilineal and matrifocal context of Minangkabau society, where Sanday (1990:142) found that 'exclusion of women from intellectual and government activities in the capital [Padang] was reminiscent of Western practices'. Members of an all-male seminar 'defended their exclusion of women on the ground that the traditional system of roles includes one defined as 
mentioned, in Tana Toraja, as all over Indonesia during this period, the New Order Government systematically enlisted the wives of civil servants and army officers into parallel, subsidiary, wives' organizations, instead of their own autonomous ones, and into organizations with a decidely domestic orientation - notably since 1974, the PKK (Pembinaan Kesejahteraan Keluarga or 'Guidance for Family Welfare' Programme), which had local cells nationwide. ${ }^{16}$ The PKK too was tightly linked to the bureaucratic hierarchy; in Tana Toraja, it was headed by the Bupati's wife. Within the terms set by this organization, women were likely to find themselves forced into the role of the 'modern housewife' idealized by the middle classes, a role whose specifications can turn out to be far more rigid than those offered by traditional options, especially in the less well-off strata of Indonesian societies.

Dutch institution-building ensured a relatively high standard of education in Tana Toraja, and compared to other regions, comparatively large numbers of Toraja today have tertiary qualifications. Toraja, by contrast with some other peoples of Indonesia, have never shown any prejudice against the education of women; however, once again, women do face practical pressures to marry relatively young, and devote themselves to their children, which hinder their gaining higher degrees in the same numbers that men have. One can only speculate about the possible effects on local societies of the images of women provided by women's magazines and television, as people become better-off and have access to more commercial, globalized forms of cultural expression. One other area of ideological change deserves mention here, and that is the shift, made almost complete over the past few decades, from the world view of the indigenous religion to that of a Calvinist version of Christianity. Whereas the former offered interesting ritual roles to women, the latter hardly does so. New attitudes of derogation may even creep in, the Middle Eastern heritage of the monotheisms providing a marked contrast to indigenous ideas: one woman friend, in a discussion of menstruation, told me that some Christians say a woman should not take part in Church ceremonies during her period, because it is 'dirty' (she used the Indonesian word, kotor). In short, when I first became acquainted with Toraja society, it seemed highly doubtful whether any of the more modernizing influences then observable offered more emancipating opportunities to women than they enjoyed already - rather the reverse. This was certainly paradoxical, considering that

\footnotetext{
"intellectual" that is assigned exclusively to men'. One suspects that here too, the dominant ideology imposed more limits on women than the local indigenous one, which does allow moral and jural authority to women in village affairs.

16 Since the end of the New Order, the organization has been significantly renamed Pemberdayaan Kesejahteraan Keluarga, or 'Empowerment of Family Welfare'; in some areas it has become more or less defunct while in others it continues along much the same lines as before.
} 
there is really nothing in indigenous social organization that would prevent women from exerting more political influence than they do at present. The great question is how far the changed political climate in post-Suharto Indonesia will open up new opportunities for women's political participation in the twenty-first century, and how women will choose to take advantage of them. It is too early to offer an answer to that question. 